\title{
Effect of gestational age and intrauterine nutrition on plasma transferrin and iron in the newborn
}

\author{
P. H. SCOTT, H. M. BERGER, CAROLINE KENWARD, P. SCOTT, \\ and B. A. WHARTON \\ From the Biochemistry Department, Selly Oak Hospital, and Sorrento Maternity Hospital, \\ Birmingham
}

\begin{abstract}
Scott, P. H., Berger, H. M., Kenward, C., Scott, P., and Wharton, B. A. (1975). Archives of Disease in Childhood, 50, 796. Effect of gestational age and intrauterine nutrition on plasma transferrin and iron in the newborn. Plasma concentrations of transferrin and iron were measured in the cord blood of babies of varying gestational age and birthweight. Transferrin and iron concentrations rose with gestational age; values in light-for-dates babies did not differ from those in babies of appropriate weight. In the last trimester of pregnancy plasma transferrin and iron concentrations in the fetus are affected by the maturity of the pregnancy but are independent of the nutritional status of the fetus. The low transferrin levels, particularly in preterm babies, may caution the use of iron especially by the parenteral route in the neonatal period, but we are wary of abandoning on this evidence alone the well tried clincial custom of giving oral iron to preterm babies who are not breast fed.
\end{abstract}

The anti-infective property of transferrin as part of the nonspecific defence system (Fletcher, 1971) may be particularly important in the small preterm baby since more specific anti-infective substances, such as the serum immunoglobulins, are present in reduced concentrations in these babies and infection is a common complication (Hobbs and Davis, 1967; Davies, 1971). Furthermore, since serum transferrin levels were low in malnourished African children (McFarlane et al., 1969) it seemed possible that babies experiencing intrauterine malnutrition (i.e. light-for-dates babies) might have similarly reduced concentrations of serum transferrin.

We have, therefore, tried to establish the effects of gestational age and intrauterine nutrition on the plasma concentrations of transferrin and iron by measuring these substances in the cord blood of babies of varying gestational age and nutritional status.

\section{Methods}

Cord blood was collected from 106 babies born at Sorrento Maternity Hospital, Birmingham, between

Received 17 February 1975.
January and September 1974. The gestational age of the babies was assessed by mother's dates, and confirmed by the obstetrician's antenatal, and the paediatrician's postnatal, assessment of maturity. Birthweight was measured with a Salter spring balance and the babies designated as appropriate weight-for-dates (weight for gestational age, sex, and parity 10-90th centile according to data of Tanner and Thomson, 1970) or light-for-dates (weight for gestation, etc. $<10$ th centile). Of the term babies (37-41 completed weeks) $31(47 \%)$ were Asian and $8(12 \%)$ West Indian; of the preterm ones ( $<37$ weeks) $12(30 \%)$ were Asian, $5(13 \%)$ West Indian, the rest were European. The blood was collected by needle aspiration of the umbilical vein, and placed in a heparinized container. This was stored at $4{ }^{\circ} \mathrm{C}$ until the plasma was separated (within 36 hours). The plasma was stored at $-20{ }^{\circ} \mathrm{C}$ until analysis.

Transferrin concentrations were measured by a single radial immunodiffusion technique (Mancini, Carbonara, and Heremans, 1965) using Behringwerke $M$ Partigen plates (Hoechst Pharmaceuticals Ltd). Each plate was standardized using standard human serum (Hoechst). Iron concentrations were determined by the method of Askevold and Vellor (1967). Percentage transferrin saturations were calculated assuming $1 \mathrm{mg}$ transferrin when fully saturated binds $1.4 \mu \mathrm{g}$ iron (Dixon, 1973). 


\section{Results}

The Fig. shows the plasma transferrin, iron, and transferrin saturation in the cord bloods of babies of different gestational ages. Concentrations of plasma transferrin and iron rose with increasing gestational age but the degree of saturation showed little change. The plasma levels of transferrin and iron in the light-for-dates babies were similar to those in the appropriate weight-for-dates group.

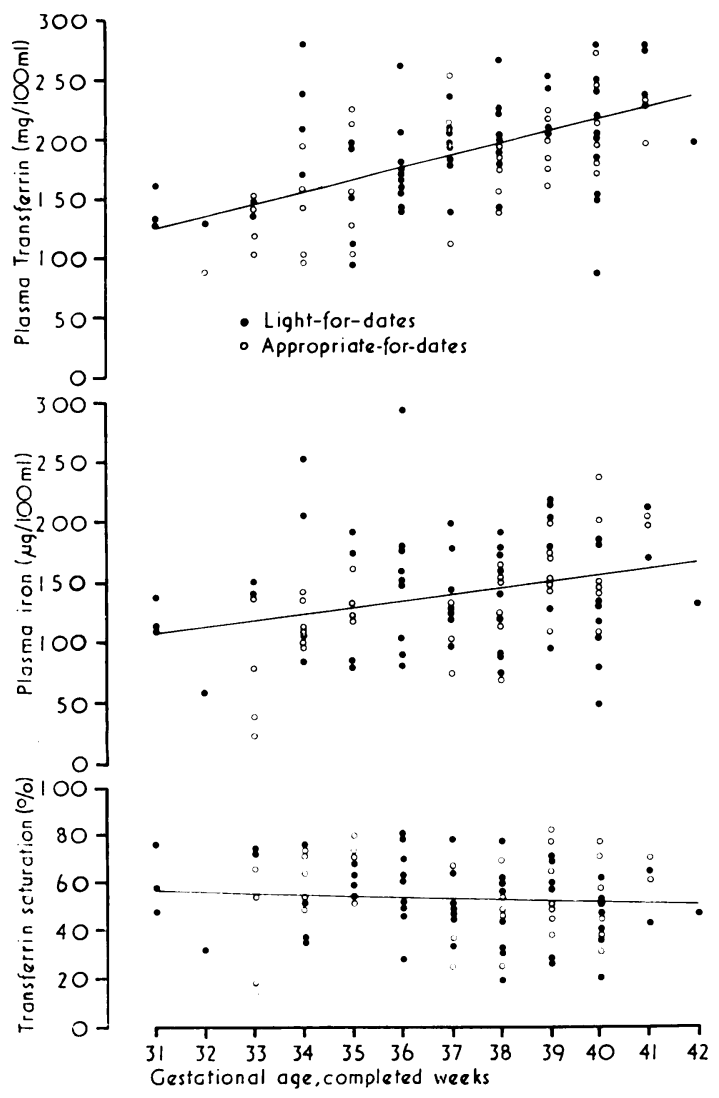

FIG.-Concentration of transferrin and iron, and percentage transferrin saturation in cord blood from babies of different gestational ages. Combining light-for-dates and appropriate weight babies for (1) transferrin $r=0.54$, $P<0.001 ;$ (2) iron $r=0.29, P<0.01 ;(3)$ transferrin saturation $r=-0 \cdot 10$, not significant. The regression lines are shown.

In term babies (37-41 completed weeks) transferrin in light-for-dates group was (mean $\pm S D, m g / 100 \mathrm{ml}$ ) $210 \pm 45$ and in appropriate weight group $200 \pm 36$, not significant; iron in light-for-dates group was $145 \pm 44 \mu \mathrm{g} /$ $100 \mathrm{ml}$ and in appropriate weight group was 151 \pm 41 , not significant.
Individual results did not show any racial differences.

\section{Discussion}

In the term babies the concentrations of iron were similar to those reported previously (Csorba, Jezerniczky and Dvorácsek, 1973; Chang and Sivasamboo, 1973) and transferrin concentrations were a little higher. Low concentrations of iron and transferrin have been reported in low birthweight babies (Csorba et al., 1973; Weippl, 1962), but the findings were not related to the presently accepted divisions of low birthweight babies into 'preterm' and 'light-for-dates' categories (European Congress of Perinatal Medicine, 1970).

Developmental biology. Our observations show that the serum transferrin rises with gestational age; since transferrin is thought not to cross the placenta in man (Gitlin et al., 1964), this rise presumably reflects an increasing rate of synthesis by the liver. The serum iron concentration increased in parallel with the transferrin. The plasma transferrin level and its degree of saturation are probably the rate-limiting steps in intestinal iron absorption (Nutrition Review, 1973; Fletcher and Huehns, 1968) so that the increase in fetal transferrin with increasing maturity might similarly determine the amount of iron transported across the placenta, and hence the increase in fetal iron stores during that period (Oski and Naiman, 1972).

Transferrin was not lower in the malnourished (light-for-dates) babies. It is interesting, however, that mothers producing a low birthweight baby may have low levels of serum transferrin at midpregnancy (Maletnlema and Eddy, 1972) and at term (Chang and Sivasamboo, 1973), though it is unclear whether the serum transferrin is reflecting the nutritional status of the mother at that time.

Clinical implications. Although the transferrin levels rose with gestational age, the scatter of results was too wide for clinical use in determining maturity, nor were the levels useful in assessing nutritional status.

The low level of transferrin, particularly as it was well saturated (mean $59 \%$ compared to about $40 \%$ in the adult; Oski and Naiman, 1972) might be related to the problem of infection in preterm babies. The concentration was very low in some individuals and it is known that it falls even further for a few days after birth before rising again, e.g. in a group of 29 preterm babies and 19 light-for-dates term babies receiving infant formulae containing iron 
approximately $1 \mathrm{mg} / 100 \mathrm{ml}$ we found the plasma transferrin at 11 days to be about $85 \%$ of that found at birth with a return to near birth levels at 21 days.

It may be in these circumstances that any measures leading to an increased transferrin saturation would prejudice further the nonspecific antiinfective role of transferrin. This would caution the use of iron (either by individual prescription or as fortification of infant formulae) in the neonatal period. However, even after the use of oral iron it seems that the degree of transferrin saturation in low birthweight babies is very low (Brozović et al., 1974). Furthermore, iron deficiency is associated with depressed white cell function in older children (Chandra, 1973) and depressed antibody production in rats (Nalder et al., 1972). We feel, therefore, we should be wary of abandoning, on the transferrin evidence alone, the well tried custom of giving supplementary oral iron to low birthweight babies who are not receiving fresh breast milk. However, our understanding of the biological functions of iron and its binding proteins in this age group is changing rapidly so that current clinical practice must be kept under review.

Parenteral iron gives a greater degree of saturation (Leikin, 1960) and we do not use it at this age, nor is oral iron given to breast-fed babies, so avoiding saturation of the lactoferrin in the breast milk (Bullen, Rogers and Leigh, 1972).

We thank Sisters King and Forrest and their staff for collection of specimens and analysis of results. H. M. B. held a Sheldon Clinical Research Fellowship of the West Midlands R.H.A., and John Wyeth gave further financial support.

\section{REFERENCES}

Askevold, R., and Vellar, O. D. (1967). A simple method for the determination of iron in serum and other biological materials. Scandinavian Fournal of Clinical and Laboratory Investigation, 20, 122.

Brozovic, B., Burland, W. L., Simpson, K., and Lord, J. (1974). Iron status of preterm low birthweight infants and their response to oral iron. Archives of Disease in Childhood, 49, 386.

^SMA or S26, John Wyeth.
Bullen, J. J., Rogers, H. J., and Leigh, L. (1972). Iron binding proteins in milk and resistance to Escherichia coli infection in infants. British Medical fournal, 1, 69.

Chandra, R. K. (1973). Reduced bactericidal capacity of polymorphs in iron deficiency. Archives of Disease in Childhood, 48,864 .

Chang, L. L., and Sivasamboo, R. (1973). Serum transferrin in cord blood and maternal blood. Fournal of Obstetrics and Gynaecology of the British Commonwealth, 80, 1013.

Csorba, S., Jezerniczky, J., and Dvorácsek, E. (1973). Serum transferrin, serum iron and total iron binding capacity: the role of transferrin in non specific immune defence. Acta Paediatrica Academiae Scientiarum Hungaricae, 14, 291.

Davies, P. A. (1971). Bacterial infection in the fetus and newborn Archives of Disease in Childhood, 46, 1.

Dixon, K. (1973). Routine clinical measurements of transferrin in human serum. Annals of Clinical Biochemistry, 10, 127.

European Congress of Perinatal Medicine (1970). Working party to discuss nomenclature based on gestational age and weight. Archives of Disease in Childhood, 45, 730.

Fletcher, J. (1971). The effect of iron and transferrin on the killing of Escherichia coli in fresh serum. Immunology, 20, 493.

Fletcher, J., and Huehns, E. R. (1968). Function of transferrin, Nature, 218, 1211.

Gitlin, D., Kumate, J., Urrusti, J., and Morales, C. (1964). The selectivity of the human placenta in the transfer of plasma proteins from mother to fetus. Fournal of Clinical Investigation, 43, 1938.

Hobbs, J. R., and Davis, J. A. (1967). Serum $\gamma$ G globulin levels and gestational age in premature babies. Lancet, 1, 757.

Leikin, S. L. (1960). The use of intramuscular iron in the prophylaxis of the iron deficiency anemia of prematurity. America Fournal of Diseases of Children, 99, 739.

McFarlane, H., Ogbeide, M. J., Reddy, S., Adcock, K. J., Adeshina, H., Gurney, J. M., Cooke, A., Taylor, G. O., and Mordie, J. A. (1969). Biochemical assessment of protein calorie malnutrition. Lancet, 1, 392.

Maletnlema, T. N. and Eddy, T. P. (1972). Serum transferrin of pregnant mothers related to birthweight of their infants British Medical fournal, 3, 386.

Mancini, G., Carbonara, A. O., Heremans, J. F. (1965). Immunochemical quantitation of antigens by single radial immunodiffusion. Immunochemistry, 2, 235.

Nalder, B. N., Mahoney, A. W., Ramakrishnan, R., and Hendricks, D. G. (1972). Sensitivity of the immunological response to the nutritional status of rats. Fournal of Nutrition, 102, 535.

Nutrition Review (1973). The role of transferrin in iron absorption, 31, 131.

Oski, T. A., and Naiman, J. L. (1972). Hematologic Problems in the Newborn, Vol. IV, p. 31. Major Problems in Clinical Pediatrics. Ed. by A. J. Schaffer. Saunders, Philadelphia.

Tanner, J. M., and Thomson, A. M. (1970). Standards for birthweight at gestation periods from 32 to 42 weeks, allowing for maternal height and weight. Archives of Disease in Childhood, $45,566$.

Weippl, G. (1962). Transferrin bei Fruhgeborenen. Zeitschrift fur Kinderheilkunde, 86, 579.

Correspondence to Dr. B. A. Wharton, Infant Development Unit, Queen Elizabeth Medical Centre, Edgbaston, Birmingham B15 2TG. 